\title{
THREE DIMENSIONAL DOWNSTREAM SCOUR ANALYSIS AFTER LEVEE OVERTOPPING
}

\author{
Sazia AFREEN 1 , Junji YAGISAWA 2 and Norio TANAKA 3 \\ ${ }^{1}$ Member of JSCE, Doctoral Student, Graduate School of Science and Engineering, Saitama University \\ (225 Shimo-Okubo, Sakura-Ku, Saitama 338-8570, Japan) \\ ${ }^{2}$ Member of JSCE, Ph.D., Associate Professor, Graduate School of Science and Engineering, Saitama University \\ (225 Shimo-Okubo, Sakura-Ku, Saitama 338-8570, Japan) \\ ${ }^{3}$ Member of JSCE, Doctor of Engineering, Professor, International Institute for Resilient Society, Saitama University \\ (225 Shimo-Okubo, Sakura-Ku, Saitama 338-8570, Japan)
}

\begin{abstract}
Three dimensional experiments are conducted to analyze the downstream scour dimensions after levee overtopping. For elucidating the difference of scour dimension under various hydraulic (overtopping flow height at the levee top, $d_{b a n k}$ ) and geometric parameters (levee height, $h_{\text {bank }}$, overtopping flow width along the levee, $\left.W_{b a n k}\right), 3 \mathrm{D}$ scour profiles are investigated. From the analysis, it has been observed that at equilibrium conditions, for the same $d_{b a n k}$ cases scour depth $\left(S_{d}\right)$ is higher for greater $h_{\text {bank }}(10 \mathrm{~cm})$ compared with lower levee height $(6 \mathrm{~cm})$. In contrast, scour length $\left(S_{l}\right)$ is longer in case of lower $h_{\text {bank }}$ compared to higher $h_{\text {bank }}$ for same $d_{\text {bank }}$. The stronger hydraulic jump that took place in case of smaller levee height cases appears to play a significant role in developing greater scour length along with shorter scour depth. Three separate equations for $S_{d}, S_{l}$ and $S_{w}$ (scour width) have been proposed from multiple regression analysis. These results can be useful for the study of levee design.
\end{abstract}

Key Words : Scour dimension, levee height, densimetric Froude number, flow dispersion, multiple regression analysis

\section{INTRODUCTION}

Levee overtopping can cause erosion at the downstream side of the structure due to flow plunging towards the downstream side. As the landside remains usually unprotected, large scour holes can be created because of the erosion near the toe of the levee at the landside ${ }^{1)}$. Land side erosion due to levee overtopping can limit levee performance and survival of the structure ${ }^{2)}$. Therefore, downstream scour hole analysis due to levee overtopping plays an important role for levee design.

Many researchers ${ }^{3), 4)}$ conducted vertical two dimensional experiments to evaluate the scour depth and length at downstream of hydraulic structures. Three dimensional scour analyses is very important for levee design, as in case of 3D experimental analysis scour depth was found to be higher compared to the 2D experimental analysis under similar experimental conditions $^{5)}$. Pagliara ${ }^{6}$ also observed larger scour depth in a symmetrically expanding stilling basin. Extent of scour depends on characteristics of flow, bed material composition and geometry of structure ${ }^{2)}$. Densimetric Froude number is the appropriate parameter which can define the mobility of the sediment particles ${ }^{7)}$.

Maximum scour is attained under clear-water scour conditions, as under live-bed scour conditions, sediment transport trapped in the scour hole can locally reduce the scour depth compared with that caused by a clear water flow ${ }^{13)}$. So laboratory experiments are often conducted under such conditions $^{8), 9)}$. Pagliara ${ }^{9)}$ demonstrated that clear-water scour condition occurs when a ridge is present downstream of the scour hole and there is no sediment transport at the downstream of the scour hole. He also mentioned that after a certain period (about $30 \mathrm{~min}$ ), the mobile bed practically reaches its final configuration, which is termed as equilibrium condition.

On the other hand, Sato and Tanaka ${ }^{10)}$ conducted field investigation for the 3D scoured region behind river and sea embankment created after the 2011 Great East Japan tsunami and clarified the impact of energy head upon scour dimensions. Pagliara ${ }^{11)}$ 
investigated 3D plunge pool scour. They introduced a parameter " $b_{m} / b$ " $\left(b_{m}\right.$ and $b$ are maximum scoured width and channel width respectively) to distinguish the scour type as 2D or 3D. Higher scour depth as well as scour width can largely affect the stability of the levee structure. On the other hand longer scour hole can destroy valuable property which is located at the downstream of the levee structure. As complete protection against scour is too expensive, generally, the maximum scour depth has to be predicted to minimize the risk of failure of the levee ${ }^{12)}$. Prediction of maximum scour length and maximum scour width is also necessary for the stability of the structure and the protection of a residential area near the levee structure. From previous studies, energy of the flow (as overtopping depth and velocity) and geometry of structure are supposed important factors for understanding the scour hole dimensions. So, it is very important to investigate the scour dimensions in relation to hydraulic and geometric parameters, which affect scouring process. However, scour dimension analysis considering 3D experiments have not been investigated yet. Therefore, objectives of this study are to 1) investigate the downstream scour dimensions $\left(S_{d}, S_{l}\right.$ and $\left.S_{w}\right)$ in 3D experiments by changing the hydraulic (overtopping flow height at the levee top) and geometric parameters (levee height, overtopping flow width along the levee) and 2) to develop equations for defining downstream scour dimensions from multiple regression analysis.

\section{MATERIALS AND METHOD}

\section{(1) Experimental setup and procedure}

For the three dimensional scour analysis, wooden levees were constructed in the experiment flume ( $3 \mathrm{~m}$ length, $4 \mathrm{~m}$ width and $0.5 \mathrm{~m}$ height). Fig.

1 represents the schematic diagram of the experimental setup.

Two levee height conditions $(10 \mathrm{~cm}$ and $6 \mathrm{~cm}$ ) were considered $\left(h_{\text {bank }}\right.$ in Fig. 1(a)). At the landside, levee slope was $1 \mathrm{~V}: 3 \mathrm{H}$ during all the experimental cases. During the experiments, overtopping water depths $\left(d_{b a n k}\right.$ in Fig. 1(a)) of 1, 2, 2.5, 3, and $4 \mathrm{~cm}$ were considered for $10 \mathrm{~cm}$ levee height and 1, 2, 3, 4 and $5 \mathrm{~cm}$ overtopping water depths were considered in case of $6 \mathrm{~cm}$ levee height. The overtopping water depth at the top of the levee was measured by a point gauge. Width of dispersed water near the levee toe $\left(W_{d}\right)$ was measured from the video of the experimental cases (Fig. 1(b)). Water overtopping width ( $W_{\text {bank }}$ in Fig. 2) was controlled by attaching the wooden boards with the levee. Four $W_{b a n k}$ of 20 , 40,60 and $80 \mathrm{~cm}$ were considered for the 3D experiments.

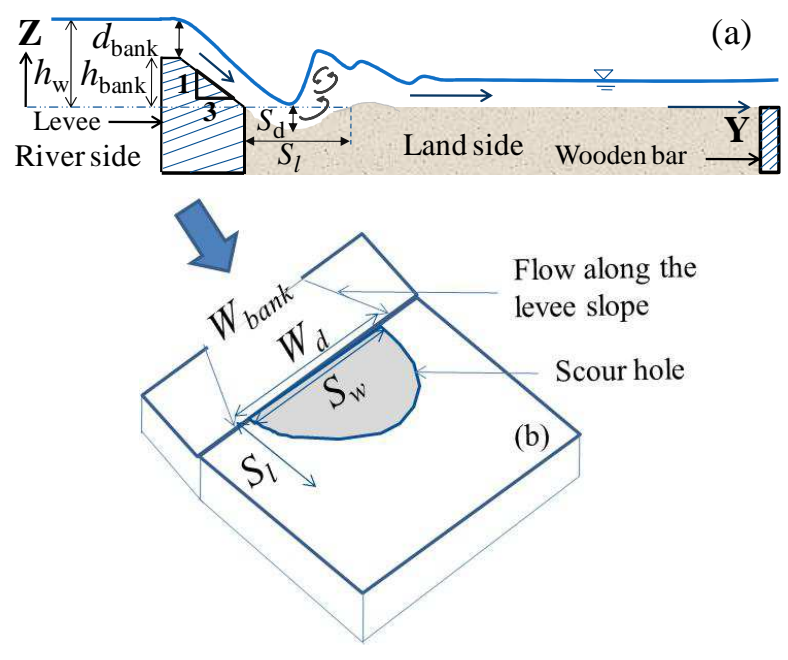

Fig.1 Schematic view of the experimental setup. (a) side view, (b) 3D view. N.B. $h_{\text {bank }}:$ levee height, $d_{\text {bank }}$ : overtopping water depth at levee crest, $h_{w}$ : combined height of levee and overtopping water level from levee top, $W_{\text {bank }}$ : overtopping width, $S_{d}$ : maximum scour depth, $S_{l}$ : maximum scour length, $S_{w}$ : maximum scour width, $W_{d}$ : dispersed water width near the levee toe

Two wooden boards with same height of the levee were attached at two edges of the overtopping flow width $\left(W_{\text {bank }}\right)$ at the riverside during each experimental case to exclude the contraction effect after overtopping the levee.

Soil having median grain size $\left(d_{50}\right)$ of $4.5 \mathrm{~mm}$ was placed at the landside of the levee over an area of $2 \mathrm{~m}$ in length and $2 \mathrm{~m}$ in width, starting from the toe of the levee. The grain size of the soil was selected for maintaining clear-water scour condition. Wooden bars (Fig. 1 and Fig. 2) having the same height of soil were fixed at each side of the soil to ensure lateral earth pressure. From some test cases it was ensured that the distance of the wooden bars were far enough not to influence the scour profile in any experimental case. After levee overtopping, free overflow occurred above these wooden bars around the soil layer. Equilibrium scour profile was achieved after 60 minutes of overflow for all the experimental cases. From some test cases for 120 minutes, it was observed that scour profile did not change over time after 60 minutes of flow.

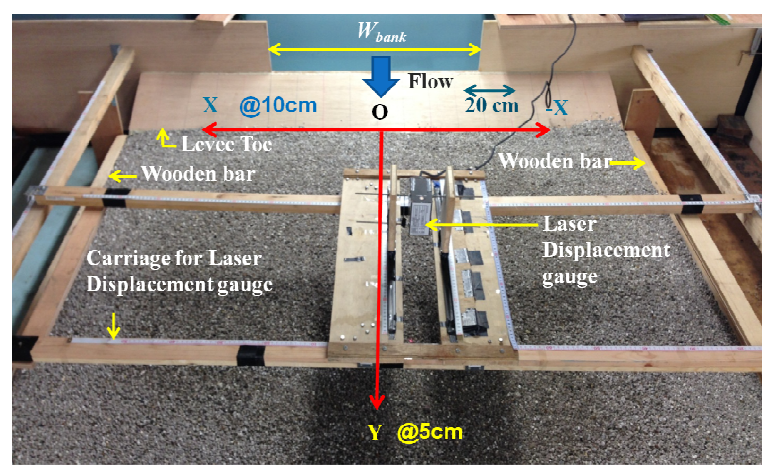

Fig.2 Three dimensional experimental setup. 
Soil surface profile was measured with the aid of laser displacement gauge (KEYENCE LK-500) after 60 minutes of overflow for all the cases. The center point of the levee toe (Point "O" in Fig. 2) is considered as origin. Scour profile data along $\mathrm{X}$ and $\mathrm{Y}$ directions were taken at every $10 \mathrm{~cm}$ and $5 \mathrm{~cm}$, respectively. Additionally, along Y direction scour data at a location $1.5 \mathrm{~cm}$ apart from the levee toe were also collected. Resolution for $\mathrm{X}$ and $\mathrm{Y}$ directions were decided from the observed scour profile in some test cases. Total 40 experimental cases were conducted with three dimensional setup.

\section{(2) Flow Dispersion Effect in case of Three Dimensional Experiments}

In the present study, levee slope for both of the levee height cases were same (1V:3H). For $6 \mathrm{~cm}$ of levee height, flow travelled less distance $(18.9 \mathrm{~cm})$ along levee slope facing less frictional resistance from the levee surface, while in case of $10 \mathrm{~cm}$ levee height cases flow travelled comparatively longer distance $(31.6 \mathrm{~cm})$. Because of less travel path in case of $6 \mathrm{~cm}$ levee height water dispersion in transverse direction was also less along the levee slope compared to $10 \mathrm{~cm}$ levee height. In Fig. 3, flow dispersion effect has been shown for $W_{b a n k}=$ $80 \mathrm{~cm}$ considering $d_{\text {bank }}=3 \mathrm{~cm}$ for both of the levee height cases. From Fig. 3(a), it can be noticed that the dispersed incoming water width along the levee toe was $125 \mathrm{~cm}$ for $10 \mathrm{~cm}$ levee height, while for the same $W_{b a n k}$ and $d_{b a n k}$ condition the dispersed incoming water width was $105 \mathrm{~cm}$ for $6 \mathrm{~cm}$ levee height (Fig. 3(b)). So, in case of $6 \mathrm{~cm}$ of levee height along the levee slope water travelled less area as it could not disperse as much as $10 \mathrm{~cm}$ levee height cases. Because of less frictional resistance, along the levee slope in case of $6 \mathrm{~cm}$ levee height conditions, comparatively stronger hydraulic jump was formed.
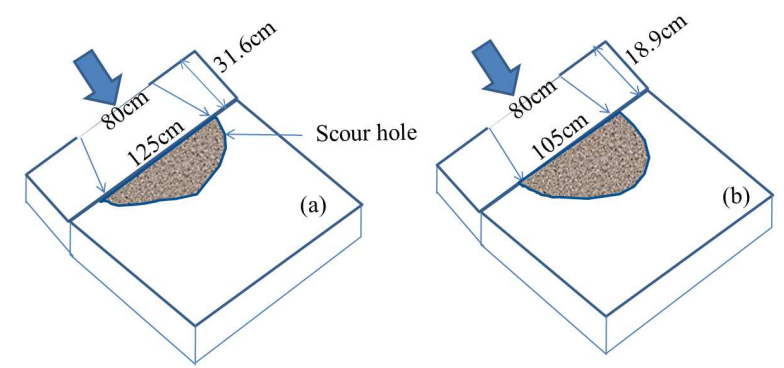

Fig.3 Flow dispersion effect for $W_{\text {bank }}=80 \mathrm{~cm}$ considering $d_{b a n k}=3 \mathrm{~cm}$ (a) $10 \mathrm{~cm}$ levee height and (b) $6 \mathrm{~cm}$ levee height.

\section{RESULTS AND DISCUSSIONS}

\section{(1) Scour Dimension Analysis}

Densimetric Froude number is an important parameter to express scour dimension. Many researchers $^{6,7), 9)}$ investigated downstream scour depth in terms of $F_{d 50}$, which can be derived from the following equation.

$$
F_{d 50}=\frac{V}{\sqrt{g . d_{50} \cdot\left(\frac{\rho_{s}-\rho}{\rho}\right)}}
$$

where, $V, g, d_{50}, \rho, \rho_{s}$ stand for overtopping flow velocity at the levee crest, gravitational acceleration, median grain size of the soil, water mass density and soil mass density, respectively. Critical velocity occurs at the levee crest, which can be calculated from $d_{\text {bank }}$ value $\left(V=\sqrt{g \cdot d_{\text {bank }}}\right)$.

Scour profile can also be expressed in terms of energy head at the top of embankment ${ }^{10)}$. The relationship between densimetric Froude number and equilibrium scour depths for 3D experiments are presented in Fig. 4 (a) considering four $W_{\text {bank }}$ $(20,40,60$ and $80 \mathrm{~cm})$ conditions. Fig. 4(b) presents the relationship between non dimensional energy head and non dimensional equilibrium scour depth including previous studies. In the present study, flow overtopped the levee in a perpendicular direction to the main stream flow. In this situation the kinematic energy is significantly less than the potential energy.

From the practical point of view, the energy head considering different overflow conditions are analyzed in the present research using Eq. (1).
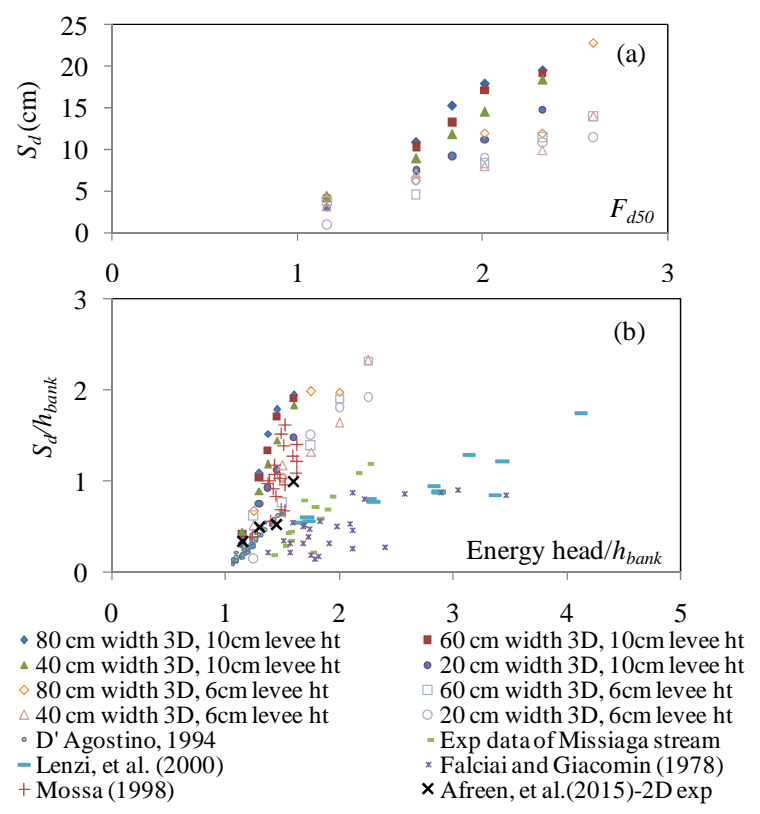

Fig.4 Characteristics of equilibrium scour depths. (a) relationship between scour depth and densimetric Froude number for present research (b) relationship between non-dimensional energy head and non-dimensional scour depth including other research results 
Energy head at the top of embankment, $E$

$=$

$$
h_{w}+\frac{v^{2}}{2 g}=h_{w}+\frac{F r^{2} g\left(h_{w}-h_{b a n k}\right)}{2 g}=h_{\text {bank }}+d_{\text {bank }}+\frac{F r^{2}}{2} d_{\text {bank }}
$$

where $h_{w}, h_{\text {bank }}$, and $d_{\text {bank }}$ stand for overtopping water level (combined height of levee and overtopping water depth from levee top), levee height, and water level from the levee top, respectively (shown in Fig. 1), and $v, g$, and $F_{r}$ stand for overtopping flow velocity, gravitational acceleration and Froude Number, respectively. At the levee crest critical flow occurs $\left(F_{r}=1\right)$. So, Eq. (2) can be written as:

$$
E=h_{b a n k}+1.5 d_{b a n k}
$$

In Fig. 4(a), scour depth can be observed higher for $10 \mathrm{~cm}$ levee height cases compared with $6 \mathrm{~cm}$ levee height cases considering same $d_{\text {bank }}$ condition (same $F_{d 50}$ ). Rate of scour depth increase is also higher for $10 \mathrm{~cm}$ levee height cases. In case of $10 \mathrm{~cm}$ of levee height flow hit the soil after travelling longer levee surface. For this levee height cases the gravitational component of the flow was larger compared to that for $6 \mathrm{~cm}$ levee height cases because of higher potential energy head. For this reason scour depth was comparatively higher in case of $10 \mathrm{~cm}$ of levee height (Fig. 4(a)). Non-dimensional 2D scour depth results ${ }^{5)}$ are plotted in Fig. 4(b), where experiment was conducted in 2D setup with $10 \mathrm{~cm}$ levee height condition while other experimental conditions being similar to the present research. Scour depth was observed higher in case of 3D experiments compared to 2D experimental cases $^{5)}$. Rest of the previous studies, plotted in Fig. 4(b) are collected from D'Agostino and Ferro ${ }^{13)}$. For most of 2D results, non-dimensional scour depth are found to be lower for similar energy head compared to the 3D results of the present study (Fig. 4(b)). Scour length in the present study has been shown as a function of densimetric Froude number in Fig. 5(a). From this figure, scour length can be higher in case of $6 \mathrm{~cm}$ levee height condition compared to $10 \mathrm{~cm}$ levee height cases for similar $d_{\text {bank }}$ with same $F_{d 50}$ condition. For $6 \mathrm{~cm}$ levee height conditions, because of higher water mass at the levee toe, comparatively stronger hydraulic jump was created. As a result longer scour hole at the downstream of the levee was formed (Fig. 5(a)). In Fig. 5(b), non-dimensional 2D scour lengths of previous studies ${ }^{5,8), 9)}$ are also plotted. 2D non-dimensional scour lengths ${ }^{5), 8)}$ are observed higher than the present study for same energy head condition. In addition, results from previous research $^{9)}$ show good agreement with the present
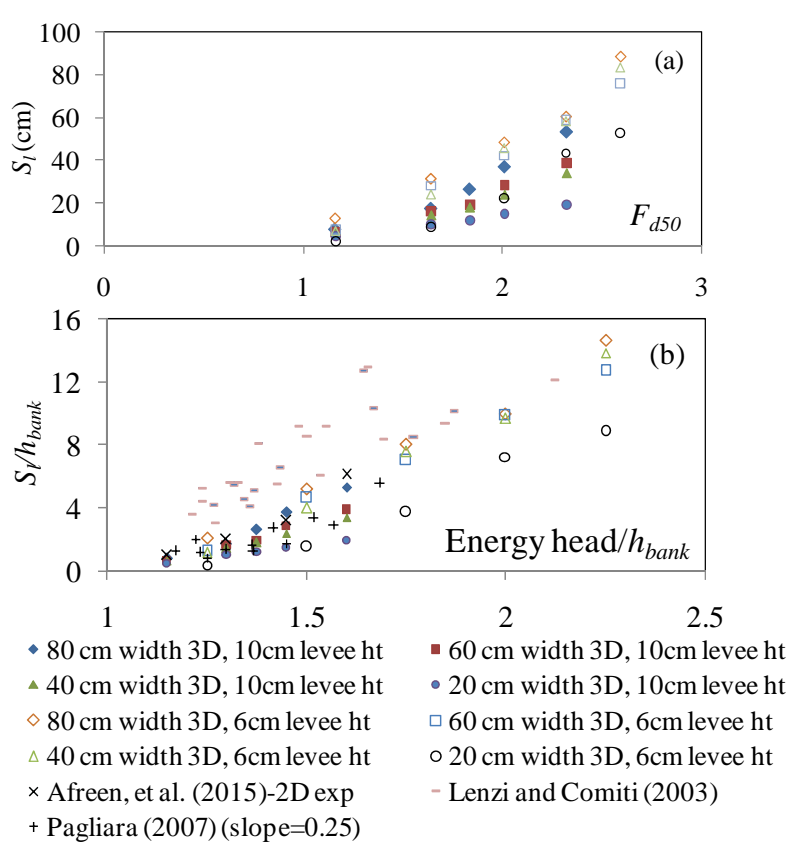

Fig.5 Characteristics of equilibrium scour lengths.

(a) Relationship between scour length and densimetric Froude number for present research, (b) Relationship between non-dimensional energy head and non-dimensional scour length including other research results

study. This is because ramp slope of 0.25 has been taken for scour length results from previous research $^{9)}$ for the comparison, which is the most representative slope (downstream slope in the present study was 0.33) among other milder slopes, considered by the study. In Fig. 6, relationship between densimetric Froude number and scour width of the present study has been presented. In spite of larger dispersed water width in case of $10 \mathrm{~cm}$ levee height condition, no significant difference in scour width is observed for $10 \mathrm{~cm}$ and $6 \mathrm{~cm}$ levee height cases for same overtopping water depth (same $F_{d 50}$ condition), which indicates that overtopping width governs the scour width dimension more than the levee height values.

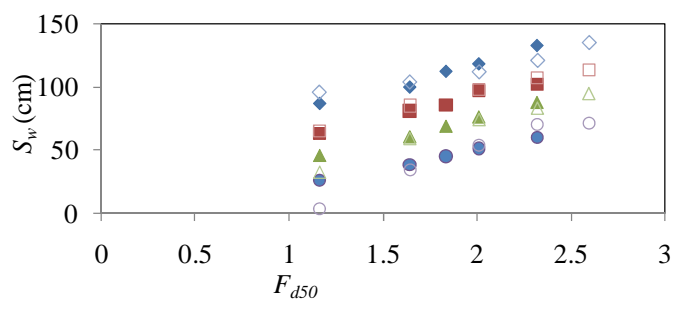

- $80 \mathrm{~cm}$ width $3 \mathrm{D}, 10 \mathrm{~cm}$ levee ht $\quad \square 60 \mathrm{~cm}$ width $3 \mathrm{D}, 10 \mathrm{~cm}$ levee $\mathrm{ht}$ $\triangle 40 \mathrm{~cm}$ width $3 \mathrm{D}, 10 \mathrm{~cm}$ levee ht $\quad 20 \mathrm{~cm}$ width $3 \mathrm{D}, 10 \mathrm{~cm}$ levee ht

$\diamond 80 \mathrm{~cm}$ width $3 \mathrm{D}, 6 \mathrm{~cm}$ levee ht $\square 60 \mathrm{~cm}$ width $3 \mathrm{D}, 6 \mathrm{~cm}$ levee ht

$\triangle 40 \mathrm{~cm}$ width $3 \mathrm{D}, 6 \mathrm{~cm}$ levee ht $\bigcirc 20 \mathrm{~cm}$ width $3 \mathrm{D}, 6 \mathrm{~cm}$ levee ht

Fig.6 Relationship between equilibrium scour width and densimetric Froude number. 


\section{(3) Multiple Regression Analysis}

From the present 3D experimental results, three separate equations have been developed considering the important parameters for scour depth, length and width. Multiple regression analysis has been conducted to obtain the general equation for defining non-dimensional scour depth $\left(S_{d} / h_{\text {bank }}\right)$ for three dimensional experiments.

Non-dimensional energy head $\left(E / h_{\text {bank }}\right)$, overtopping water depth $\left(d_{b a n k} / h_{\text {bank }}\right)$, overtopping width $\left(W_{\text {bank }} / h_{\text {bank }}\right)$ and densimetric Froude number $\left(F_{d 50}\right)$ have been considered as the independent variables. From the multiple regression analysis, P-value (0.32) for $E / h_{\text {bank }}$ is found higher than 0.05 (significance level, $\alpha$ ), which indicates this variable is not associated with changes with the dependent variable. Therefore, after excluding non-dimensional energy head, the following equation has been obtained for defining non-dimensional scour depth.

$$
\frac{S_{d}}{h_{\text {bank }}}=-2.31\left(\frac{W_{\text {bank }}}{h_{\text {bank }}}\right)^{0.303}\left(\frac{d_{\text {bank }}}{h_{\text {bank }}}\right)^{-0.25}\left(F_{d 50}\right)^{2.71}
$$

P-values for $W_{\text {bank }} / h_{\text {bank }}, d_{\text {bank }} / h_{\text {bank }}$ and $F_{d 50}$ are $4.13 \times 10^{-5}, 9.71 \times 10^{-2}, 1.62 \times 10^{-9}$, respectively, which are less than 0.05 . For this regression analysis, adjusted $\mathrm{R}^{2}$ value (decision coefficient) is 0.89 , which indicates the above equation explains all the variability of the response data around its mean. Fig. 7 shows the comparison of calculated values of non-dimensional scour depth using Eq. (4) with experimental values ${ }^{5), 14)}$. In addition, some other experimental data obtained from D'Agostino and Ferro $^{13)}$ are included in the same figure. From the figure it is evident that except one set of data, all the 2D experimental scour depth values are smaller than the calculated values obtained from presently developed equation for $3 \mathrm{D}$ cases shown by the line because of lateral boundary effect and absence of flow recirculation in 2D cases ${ }^{5,6}$. The experimental data ${ }^{13)}$ which nearly matches with the developed equation is the one from the previous work of same author in 1994, actually considered expansion of the channel after overtopping thereby representing a partially 3D case. For defining non-dimensional scour length $\left(S_{l} / h_{\text {bank }}\right)$, multiple regression analysis has been conducted using the data in present 3D experiments. Initially $\mathrm{E} / h_{\text {bank }}, d_{\text {bank }} / h_{\text {bank }}, W_{\text {bank }} / h_{\text {bank }}$ and $F_{d 50}$ have been considered as the independent variables. Again the P-value (0.17) for non-dimensional energy head is higher than 0.05 from the multiple regression analysis. After excluding non-dimensional energy head, Eq. (5) has been obtained for defining non-dimensional scour

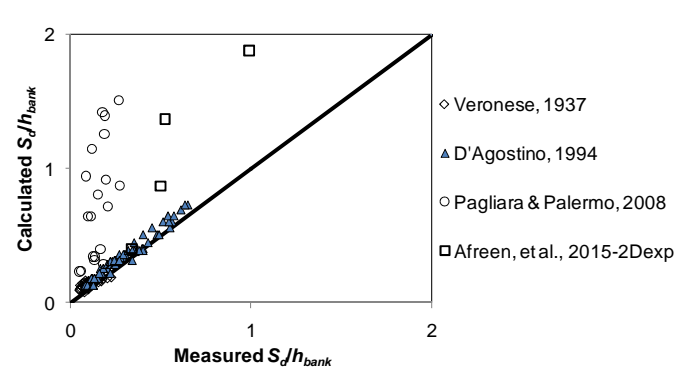

Fig.7 Relationship between measured non-dimensional scour depths with calculated non-dimensional scour depths.

$$
\frac{S_{l}}{h_{\text {bank }}}=2.475\left(\frac{W_{\text {bank }}}{h_{\text {bank }}}\right)^{0.576}\left(\frac{d_{\text {bank }}}{h_{\text {bank }}}\right)^{1.083}\left(F_{d 50}\right)^{0.656}
$$

length. P-values for $W_{b a n k} / h_{b a n k}, d_{b a n k} / h_{\text {bank }}$ and $F_{d 50}$ are $3.83 \times 10^{-11}, 4.53 \times 10^{-09}, 4.88 \times 10^{-02}$, respectively, which are less than 0.05 . From the regression analysis, decision coefficient is 0.96 , which indicates the above equation explains all the variability of the response data around its mean. In Fig. 8, a line has been drawn from the experimental non-dimensional 3D scour lengths of the present study and the calculated non-dimensional scour length values following Eq. (5). The 2D experimental scour lengths of other researchers ${ }^{5), 9), 14)}$ and calculated results using Eq. (5) for 3D experiment have also been plotted in Fig. 8. Scour length values of Pagilara ${ }^{9)}$ considering block ramp slope 0.25 has been presented in Fig. 8. Scour length results of 2D cases from other researchers ${ }^{5), 9), 14)}$ are larger than the calculated scour length results following Eq. (5) for 3D cases of the present study due to absence of lateral flow dispersion ${ }^{5}$.

For defining non-dimensional scour width $\left(S_{w} / h_{\text {bank }}\right)$, multiple regression analysis has also been conducted using the data in present 3D experiments. Initially $\mathrm{E} / h_{\text {bank }}, d_{\text {bank }} / h_{\text {bank }}, W_{\text {bank }} / h_{\text {bank }}$ and $F_{d 50}$ have been considered as the independent variables. From the multiple regression analysis, non-dimensional energy head and overtopping water depth can be excluded ( $\mathrm{p}$ values are 0.56 and 0.52 respectively). Finally after exclusion of these parameters,

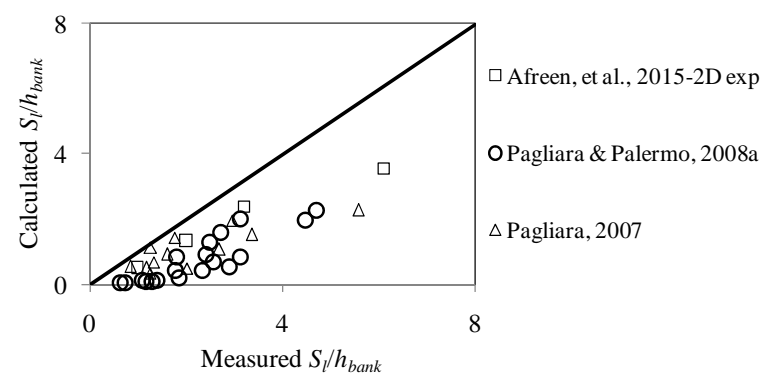

Fig.8 Relationship between measured non-dimensional scour lengths and calculated non-dimensional scour depths 


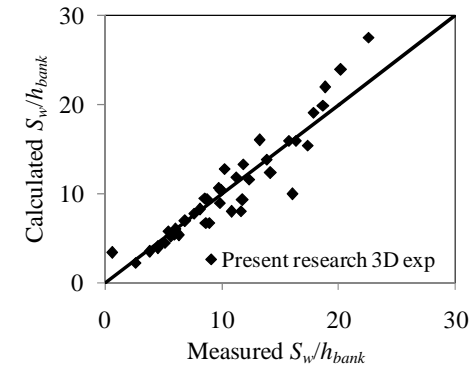

Fig.9 Relationship between measured non-dimensional scour widths with calculated non-dimensional scour depths

following equation has been obtained for defining non-dimensional scour width.

$$
\frac{S_{w}}{h_{\text {bank }}}=1.076\left(\frac{W_{\text {bank }}}{h_{\text {bank }}}\right)^{0.785}\left(F_{d 50}\right)^{1.263}
$$

From the regression analysis, decision coefficient is 0.75 . P-values for $W_{\text {bank }} / h_{\text {bank }}$ and $F_{d 50}$ are $2.28 \times 10^{-10}$, $2.69 \times 10^{-7}$ respectively, which are less than 0.05 . In Fig. 9, experimental non-dimensional 3D scour widths of the present study have been compared with the calculated non-dimensional scour width following Eq. (6). Previous experimental data of scour width is not available.

\section{CONCLUSIONS}

Levee overtopping can induce landside scouring, which affect levee stability as well as it may also hamper the property remaining at the downstream side of the levee. In the present research three dimensional scour analysis has been conducted after levee overtopping in response to different hydraulic and geometric parameters. From the scour dimension analysis, it has been observed that at the equilibrium stage scour depth was higher for higher levee height $(10 \mathrm{~cm})$ cases compared with lower levee height $(6 \mathrm{~cm})$ conditions considering same $d_{\text {bank }}$ cases (similar $F_{d 50}$ condition). Scour depth increasing rate is also comparatively higher for higher levee height $(10 \mathrm{~cm})$. On the other hand, at the equilibrium stage scour length is larger in case of lower levee height $(6 \mathrm{~cm})$ compared to higher levee height $(10 \mathrm{~cm})$ for same $d_{b a n k}$. The shorter distance travelled in case of lower levee height, cause lower dispersion and lesser frictional loss resulting higher water depth at levee toe. This creates stronger hydraulic jump in case of smaller levee height $(6 \mathrm{~cm})$.

From multiple regression analysis, three equations have been developed for the scour dimension $\left(S_{d}, S_{l}, S_{w}\right)$ from 3D experimental results of the present study. These equations can be used for the study of levee design.
ACKNOWLEDGMENT: This study was partly funded by a JSPS Grant-in-Aid for Scientific Research (B) (No. 24310127) and JSPS Grant-in-Aid for Young Scientists (B) (26821097).

\section{REFERENCES}

1) Shuto, N.: Damage to Coastal Structures by Tsunami-Induced Currents in the Past, Journal of Disaster Research. Vol.4, No.6, 2009.

2) Dehghani, A.A., Bashiri, H., Meshkati, S.M.E.: Local scouring due to flow jet at downstream of rectangular sharp-crested weirs, Water and Geoscience 5th IASME WSEAS, Cambridge, UK, 127-131, 2010.

3) Termini, D.: Bed scouring downstream of hydraulic structures under steady flow conditions: Experimental analysis of space and time scales and implications for mathematical modeling, Catena, 84, pp. 125-135, 2011.

4) Amoudry, L.O. and Liu, P.L.-F.: Two-dimensional, two-phase granular sediment transport model with applications to scouring downstream of an apron, Coastal Engineering, Vol. 56, No. 7, pp. 693-702, 2009.

5) Afreen, S., Yagisawa, J., Binh, D. V. and Tanaka, N.: Investigation of scour pattern downstream of levee toe due to overtopping flow, Annual Journal of Hydraulic Engineering, JSCE, Vol.71, No. 4, pp. I_175- I_180, 2015.

6) Pagliara, S., Palermo, M. and Carnacina, L.: Scour and hydraulic jump downstream of block ramps in expanding stilling basins, Journal of Hydraulic Research, Vol. 47, No. 4, pp. 503-511, 2009.

7) Dey, S. and Sarkar, A.: Scour downstream of an apron due to submerged horizontal jets, Journal of Hydraulic Engineering, Vol. 132, No. 3, 2006.

8) Lenzi, M.A. and Comiti, F.: Local scouring and morphological adjustments in steep channels with check-dam sequences, Geomorphology, Vol. 55, pp. 97-109, 2003.

9) Pagliara, S.: Influence of Sediment Gradation on Scour Downstream of Block Ramps, Journal of Hydraulic Engineering, Vol. 133, No. 11, 2007.

10) Sato, M. and Tanaka, N.: Quantitative Analysis on the Damage of River Embankment and Hinterland along the Abukumagawa River at the Great East Japan Earthquake Tsunami. Proc. 2013 IAHR Congress, Beijing. (A11354: Electric version), 2013.

11) Pagliara, S., Amidei, M. and Hager, W. H.: Hydraulics of 3D Plunge Pool Scour, Journal of Hydraulic Engineering, Vol. 134, No. 9, 1275-1284. September 1, 2008.

12) Khwairakpam, P. and Mazumdar, A.: Local Scour Around Hydraulic Structures, International Journal of Recent Trends in Engineering, Vol. 1, No. 6, 2009.

13) D'Agostino, V. and Ferro, V.: Scour on alluvial bed downstream of grade-control structures, Journal of Hydraulic Engineering. Vol. 130, No. 1, pp. 1-14, 2004.

14) Pagliara, S. and Palermo, M.: Scour control and surface sediment distribution downstream of block ramps, Journal of Hydraulic Research, Vol. 46, No. 3, pp. 334-343, 2008a.

(Received September 30, 2015) 